\title{
A New Computer Network Aided English Classroom Teaching Mode Wan Li-li ${ }^{1}$, Liu Yan², Wei Qiang ${ }^{3}$

\author{
(1.2 College of Humanities, Jiangxi University of Traditional Chinese Medicine, Nanchang \\ Jiangxi 330004, China
}

(3. College of Civil Engineering, Xi'an University of Architecture and Technology, Xi'an Shanxi 710055, China

Keywords: Computer network; Aided; English classroom teaching; New mode

\begin{abstract}
With the development of computer technology, computer has already been applied to all aspects of life. It has brought great changes to people's life and influences on school education. Since curriculum reform, English teaching has been put forward higher requirements. In order to improve students' English level, new teaching mode must be carried out. Effectively combine with computer to promote the integration between computer and textbooks.
\end{abstract}

\section{INTRODUCTION}

As early as in 2004, Curriculum Requirements has been promulgated in our country. This requirement has clearly put forward the request for the combining of computer multimedia and classroom. To transform from traditional English classroom to multimedia classroom, the new English teaching mode is established on the basis of the development of computer technology. And it is also the requirements of the era and new social development, and it is the world education development trend. This mode has very big superiority, but in the implement process of the new mode in our country, there are many problems need to be solved.

\section{THE ADVANTAGES OF COMPUTER NETWORK AIDED ENGLISH CLASSROOM TEACHING}

A. It breaks the limitation of "classroom + textbooks"

Traditional English classroom is the combination of teachers, students and textbooks. In the traditional classroom, teachers are in dominance, which gives full play to the teacher's leading role, but the students' main body status has not been respected. This class mode simply works as teachers impart textbook knowledge to the student according to the textbook, and textbook is the only medium between teachers and students. The teacher actively teaches while students are in a passive state. Students are the objects to whom teachers impart knowledge. In the face of such situation, even if there is a computer, multimedia, as auxiliary means of teaching, still is an extra media for the teacher to impart the textbook knowledge to students. It is essentially the same as the traditional mode, and not better than it. Teaching transforms from the traditional instruction to full screen irrigation. The advent of computer, to a certain extent, just enhances the teaching of the teacher, but cannot break the limitations of traditional class and textbooks.

Only by computer and curriculum integration can effectively change the limitation of "classroom + textbook". The mutual integration between them can promote the change of teaching framework, so this change is fundamental.

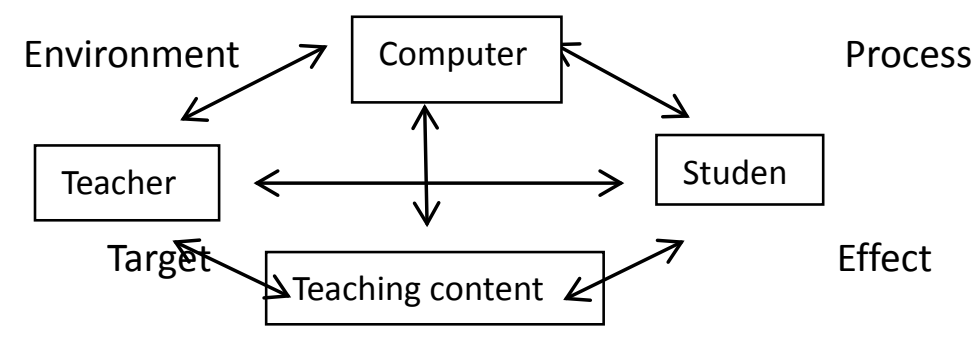


In integration classroom of computer and curriculum, each contents and the influence between each other are no longer one-way but mutual. They inter-depend on each other, promote each other, and influence each other. Teachers and students are not two separate main bodies. Teachers no longer ignore students, and students no longer passively study. Create a good atmosphere by continuous interaction and coordination.

\section{B. Teaching form diversification}

Compared with teachers, blackboard and other simple static teaching tools in traditional classroom, the new computer aided English classroom teaching mode is very novel for students and teachers both. With a computer, students hear not only the teacher's voice or their own voice. English classroom need more English listening material, and computer just meets this need of students to learn English, which changes too single listening material in the past and improves students' listening level. Traditional cramming teaching is not conducive to improve students' initiative of learning English. Students in this teaching mode have high scores but low competence. Teachers in traditional English class just simply read, and students listen, and then recite and dictate. The teaching series are boring. Learning a language is originally in order to master a kind of communication tools, but the traditional teaching put it to knowledge fact study. There is no corresponding actual practice training. Under the influence of exam-oriented education, teachers and students attach great importance to reading, writing, and test, etc., and have totally ignored the focus of attention to really master a foreign language. Lacks of corresponding training, students lack the desire to learn English and use English, which binds students' learning motivation and impedes the development of their potential.

The emergence and development of computer multimedia is gradually applied into English classroom teaching, which broke the traditional inflexible teaching methods. Modern teaching means promotes teacher teaching way diversification. With computer multimedia auxiliary, teachers of English teaching feel a lot easier to attract students' attention and improve students' positive initiative. Give full play to the teachers' leading role and respect student's main body status. The communication between teachers and students are more frequent, and a variety of teaching methods can promote students happily study in classroom and make students actually put themselves into English classroom.

\section{Students' learning ways diversity}

Computer multimedia auxiliary teaching not only brings convenience to teacher teaching, also brings changes to students learning. English, as a language, needs understanding and memorizing. The process of learning a language is inseparable from coordination operations between eyes, ears, and mouth. Only with synchronization between them can students be promoted to achieve good learning effect. Once lack effective coordination of one organ, it will not be able to reach the corresponding learning effect. Multimedia auxiliary teaching can make English learning interesting. At the time of learning English words and sentences, there is no longer just the teacher's voice, and the students can hear accurate pronunciation through multimedia. They can also see the image and animation. Multimedia functions can fully mobilize students' various senses, stimulate students' enthusiasm and initiative, and raise students' interest in learning. This will improve students learning effect. With multimedia auxiliary, students can put more attention on learning. Moreover it also can strengthen the connection between knowledge and put originally isolated knowledge together for students so as to improve the level of students' English learning.

\section{Learning efficiency improvement}

Traditional English classroom teaching is a kind of simple process. Lack of communication between teachers and students, teachers simply teaches students in classroom. The class is boring. With the application of computer multimedia, elaborated course-ware is shown in front of the students, which includes the teacher's teaching thought and teaching structure. Full of teacher's work, it is not only a course-ware, but an artistic work. Multimedia teaching can show a lot of pictures, video and sound, the enthusiasm of students is fully mobilized. It promotes students actively thinking and problems discussion, which changes the passive state so as to improve students' thinking ability and problem solving skills. It improves the efficiency of learning. 


\section{THE EXISTING PROBLEMS AND COUNTERMEASURES OF THE NEW MODE}

\section{A. Problems}

Through relevant investigation, many teachers think computer multimedia auxiliary teaching is helpful to promote students' learning and improve students' interest, but they also reflect another problem, that is their preparation time and amount of preparation are bigger than before. They need to do a lot of teaching design, course-ware design and learning material supplementing teaching, so the preparation before class becomes more onerous. Many teachers felt that the use of computers can reduce the workload and reduce stress at work, but only after using, they feel work pressure is bigger. So many teachers complain about it. In the face of such situation, teachers should change their concepts and reconsider their position.

\section{B. Countermeasures}

(1) The change of teachers' concept and role relocation

1. Concept change. To change teacher's negative emotion, first change the idea of teachers. Every teacher should fully realize the computer's important role in foreign language teaching. The development of computer greatly changed people's life. Computer aided teaching is the trend of the world development and computer aided teaching, to a great extent, changed the disadvantages of traditional teaching. It not only provides teachers teaching a variety of teaching methods and means, and to a large extent also inspires students learning initiative. It improves students' interest in learning and the efficiency of English classroom teaching. After Course Requirements promulgation, in particular, computer is no longer just a teaching tool in English teaching. Along with computer and curriculum integration, computer turns from a simple teaching aid to an indispensable organic part of English courses. As an organic part, it gives full play to its advantages, and on this basis the enthusiasm and creativity of teachers and students are fully stimulated. English classroom cannot completely abandon the characteristics of traditional classroom, also cannot ignore the supplementary role of the computer. Only by organically integration of the two can English classroom teaching be better promoted and the effect of classroom teaching is improved.

2. Role relocation. With the application of computer, teachers must change their traditional role in traditional classroom. In traditional classroom, teacher is a lecturer. For a long time, our country's English class is conducted in traditional classroom. Teachers teaching and students taking notes are the main characteristics. Problem solving and check test are the main class activities. Students learning and teacher's teaching are in a relatively passive state. Under the new teaching mode, teachers must redefine their role. On the basis of having a new understanding of teaching structure, teachers make use of the advantage of computer for knowledge acquisition and learning and teaching. Computers can promote teachers' clear teaching goal and teaching structure optimization. After combining with the characteristics of students' learning, reasonably arrange the whole class. In the new mode, teachers are no longer the image of educators in traditional sense, but shouldering the responsibility of the designer and learning facilitator. The teacher is no longer just an interpreter, but he also provides students with abundant resources, creates a good learning environment, promotes the cooperation between students learning and makes progress together. He can also understand students' learning situation in a timely manner, and guide and solve students' learning problems in a timely manner. Here the teacher also serves as a manager and plays an important role in coordinating the classroom. The role of teacher changes from previous single one to a coexisting combination of multiple roles. The teacher should have a clear understanding and perform his duties.

(2) Respect the principal position of students

Students are the main body in learning. Only by giving full play to student's main body role and respecting the principal position of students can make them get into learning better. Change the image of students in traditional teaching and turn it into an image of active learning. Under multimedia environment, students can learn in teams. With the support of resources, independently complete study tasks. This not only can improve students' learning ability, but can improve students' practical ability. Active learning often can make students' knowledge more solid. In addition, the integration between computer and courses provides students with learning information. 
More important is that it promotes students independent exploration under the guidance of problems and tasks. In the process of exploring, the students' knowledge structure, communication ability, and application ability are fully mobilized, which is not only beneficial to the students' familiarity with computer operation and improves the technical ability of students. Also it can effectively improve their learning ability and improve the efficiency of learning.

Students' subject position emphasizes the teaching principle of students-orientation. Only in this way can students' interest in learning be fully mobilized. Arouse students' exploration interest in research issues and keep them in high learning attitude. Change students' negative emotions and pay efforts to cooperate with teacher's teaching. Strengthen the interaction between teachers and students so as to create a good learning atmosphere.

\section{CONCLUSION}

The popularity of computer has brought great influence to people's life and to school education. Traditional education classroom mode is gradually changing to computer aided classroom mode. Since curriculum reform, English teaching has been put forward higher requirements. In order to improve students' English level, new teaching mode must be carried out. Effectively combining with computer, the new mode promotes the integration between computer and textbooks. This mode is established on the basis of the development of computer technology, which is in line with the Times, new requirements of social development, and has very big superiority. It breaks the limitation of "class + textbook", promotes teaching form diversification and students' learning diversity and improves learning efficiency. But in the process of implementation of the new mode in our country, teachers should actively change their concept of education and rethink its role orientation. Give full play to student's main body role and avoid detours like traditional education mode.

\section{REFERENCES}

[1] Chen Jianlin. The organic integration of computer network and curriculum under college English teaching new mode----computer "auxiliary" ecology study of the concept of foreign language teaching [J]. Computer-assisted Foreign Language Education, 2006: 3-10.

[2] Huang Fang. Computer network aided English teaching new patterns [J]. Computer-assisted Foreign Language Education, 2007, 05:43-48.

[3] Zhao Xuemin. The integrated mode of computer network and business English teaching [J]. Computer-assisted Foreign Language Education, 2009, 2009:33 to 37.

[4] Chen Jianping. Computer network auxiliary exploration and practice of college English teaching [J]. Journal of Education and Profession, 2008 01:163-165.

[5] Yang Xiaohong. Computer aided English teaching mode exploration [J]. Journal of CPC Zhuhai Municipal Party Committee Party School Zhuhai Administration College, 2008 01:61-64. 